Bulletin of the Biometric Soc. of Japan

Vo1.12, No.1 \& No.2(1991). pp.15-33

\title{
Application of Multidimensional \\ Normal Distribution Model to Clinical Repeated Measures
}

\author{
Akifumi Yafune ${ }^{1}$ and Makio Ishiguro ${ }^{2}$ \\ 1:The Kitasato Institute, 5-9-1, Shirokane, Minatoku, Tokyo 108, Japan \\ 2:The Institute of Statistical Mathematics, 4-6-7, Minami-Azabu, Minatoku, \\ Tokyo 106, Japan
}

\begin{abstract}
In this paper, we examine several models to describe the behavior of the repeated measures of blood pressure obtained in a clinical phase-one study.

Proposed models are obtained by parametrizing the mean vector and the covariance matrix of a multidimensional normal distribution model. Models are fitted to data-sets obtained from healthy male volunteers in a clinical phase-one study. AIC(Akaike Information Criterion) value of each model is calculated and the model which minimizes AIC is adopted as the most appropriate model. We simulate the data by this model and compare them with original data for the visual check of the goodness of the model.

The final model will be applicable not only to our data but also to other similar clinical repeated measures.

\section{1 緒言}

新薬開発の過程において、臨床試験と呼ばれる一連の試験があり、第 1 相から第 4 相まで の 4 段階の試験が実施される。第 1 段階としての臨床第 1 相試験では、動物を用いた前臨床試験 を終えた薬剤について、その安全性確認が主目的となる。この試験では通常 1 種類の薬郕が健康 成人男子ボランティアに投与され、投薬前および投薬後の所定の時刻に血圧、脈拍数を含めた臨 床検查が反復され、これらのデータをもとに投与された薬剤の安全性が検討される。

安全性の検討に際しては、反復測定された検査データの值のみならず、それらの動き方が重要 である。すなわち、薬剤を投与していない時のデータの動き方と薬片を投与した時のデータの動 き方の間に差がないかどうかという点が重要となる。この差を捉えるためには、まず、薬剤を投 与していない状態での臨床検查データの動き方を把握しておく必要がある。

本論文では、臨床第1相試験において、健康成人男子ボランティアから反復測定された血圧の データについて、AIC を基準としたモデル選択の立場から、その動き方に関する解析を試みる。

\section{2 データ}

解析対象となるデータは、臨床第 1 相試験において、20人の健康成人男子ボランティてか ら反復測定された血圧のデータである。この試験では、各ボランティアについて、る時点( $8: 30$. 10:00,11:00,12:00,13:00) で安静座位 3 分後に血圧を測定した。この方法による測定を、同一の20 人のボランティアについて、2 日の間隔をおいて2 回実施した。各測定において、収縮期 (Systole) 血圧と拡張期 (Diastole) 血圧が一組のデータとして得られる。
\end{abstract}

Key words: Clinical repeated measures; Clinical phase-one study; Human blood pressure; Multidimensional normal distribution; AIC. 
この期間中、ボランティアには全く薬剤は投与されず、また、外部からの影響を出来るだけ排 除するために、北里研究所内の臨床武験施設にて全員を管理した。

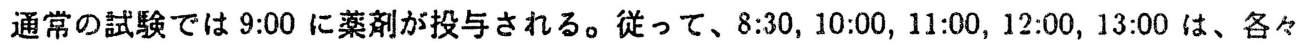
投薬前、投薬後 $1,2,3,4$ 時間目にあたる。今回、血圧湘定の時刻を上記の様に設定した理由は、投

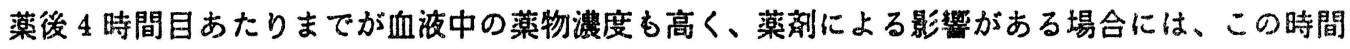
帯に現わ机る可能性が強いと考えたためである。

各ボランティアについて、2 日の間隔をおいて 2 回測定しているので、データを測定した時期 により、第 1 期 (First Period) と第 2 期 (Second Period) の 2 時期にデータを分ける。

各データには、ボランティア番号、测定時期、湘定時刻、収縮期および拡張期を表わす 4 個の 添字 $i, p, h, b$ が付けられる。各添字は次に示す值をとる。

$$
i=1,2, \cdots, 20 \quad p=\left\{\begin{array}{ll}
1 & \text { (First Period) } \\
2 & \text { (Second Period) }
\end{array} \quad h=\left\{\begin{array}{ll}
0 & (\text { Ohr.: 8:30) } \\
1 & (1 \mathrm{hr} .: 10: 00) \\
2 & (2 \mathrm{hr} .: 11: 00) \\
3 & (3 \mathrm{hr} .: 12: 00) \\
4 & (4 \mathrm{hr} .: 13: 00)
\end{array} \quad b= \begin{cases}s & \text { (Systole) } \\
d & \text { (Diastole) }\end{cases}\right.\right.
$$

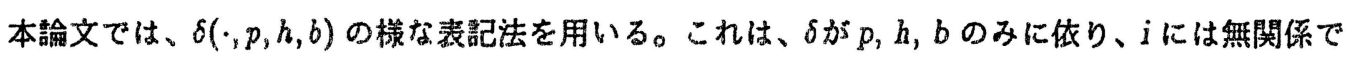
あることを表わす。

\section{3 モデル}

\section{1 多次元正規分布モデル}

$k$-次元正規分布の確滵密度関数は、

$$
f_{k}\left(x_{i}\right)=\left(\frac{1}{2 \pi}\right)^{k / 2}(\operatorname{det} \Sigma)^{-1 / 2} \exp \left\{-\frac{1}{2}\left(x_{i}-\mu\right)^{T} \Sigma^{-1}\left(x_{i}-\mu\right)\right\}
$$

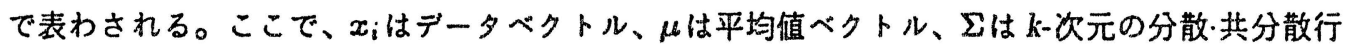
列（正定值行列）、det $\Sigma$ と $\Sigma^{-1}$ は各々 $\Sigma$ の行列式と逆行列を表わす。今回は、各ボランティてにつ いて、 5 時点で 2 時期に血压を測定している。そして、各測定において、収箖期·拡張期血圧が一 組のデータとして得られることから $k=20$ となる。各データ $x_{i}$ は

$$
x_{i}=\left(\begin{array}{c}
x_{i(1)} \\
x_{i(2)}
\end{array}\right) \quad x_{i(p)}=\left(\begin{array}{c}
x(i, p, 0, s) \\
x(i, p, 1, s) \\
\vdots \\
x(i, p, 4, s) \\
x(i, p, 0, d) \\
x(i, p, 1, d) \\
\vdots \\
x(i, p, 4, d)
\end{array}\right)
$$

と表わされる。

データの值を Appendix に、また、グラフを Figure 1-1 Figure 2-2 に示す。グラフ中の0.1， $2,3,4$ hr. は各々 8:30,10:00, 11:00, 12:00, 13:00 を表わす。各時期の平均值べクトル、分散·共分散 行列、相関行列を Table 1 と Table 2 に示す。

各時期の相関行列から、以下の点が示唆される。 
1. 収縮期血圧のデータ間および拡張期血圧のデータ間には、いずれる正の相関を認める。

2. 各測定点における収縮期血圧と拡張期血圧の間には、高い正の相関を認める。

3.上述した相関は、両時期でほぼ同様の值をとる。

4. 第 1 期の 8:30 (0hr.) の平均值は、第 2 期に比べて明らかに高い。

5. 10:00 (1hr.), 11:00 (2hr.), 12:00 (3hr.), 13:00 (4hr.) の平均值を比較すると、第 1 期の方が いずれの測定時刻においてすやや高い値をとる。

Table 1. 第 1 期 (First Period)

（平均值ベクトル）

$(114.90,113.95,111.15,110.40,109.45,73.40,70.50,68.15,65.80,67.70)^{T}$

(分散·共分散行列)

$\left.\begin{array}{ccccccccccc}112.69 & 79.69 & 84.66 & 64.64 & 96.80 & 81.94 & 85.35 & 53.61 & 39.38 & 58.97 \\ 79.69 & 139.55 & 82.01 & 65.67 & 96.67 & 44.82 & 102.72 & 46.71 & 40.49 & 69.09 \\ 84.66 & 82.01 & 120.13 & 64.99 & 102.78 & 48.29 & 78.42 & 68.73 & 53.38 & 62.30 \\ 64.64 & 65.67 & 64.99 & 87.54 & 62.12 & 54.14 & 51.10 & 44.04 & 52.73 & 46.37 \\ 96.80 & 96.67 & 102.78 & 62.12 & 172.45 & 69.87 & 107.22 & 60.08 & 53.09 & 91.28 \\ 81.94 & 44.82 & 48.29 & 54.14 & 69.87 & 77.64 & 57.30 & 38.39 & 33.28 & 45.97 \\ 85.35 & 102.72 & 78.42 & 51.10 & 107.22 & 57.30 & 108.45 & 44.13 & 33.50 & 64.20 \\ 53.61 & 46.71 & 68.73 & 44.04 & 60.08 & 38.39 & 44.13 & 64.83 & 34.28 & 36.80 \\ 39.38 & 40.49 & 53.38 & 52.73 & 53.09 & 33.28 & 33.50 & 34.28 & 48.46 & 38.99 \\ 58.97 & 69.09 & 62.30 & 46.37 & 91.28 & 45.97 & 64.20 & 36.80 & 38.99 & 82.61\end{array}\right)$


Table 2. 第 2 期 (Second Period)

(平均值ベクトル)

$(103.40,112.30,109.40,107.95,109.10,63.00,67.00,65.85,65.80,66.55)^{T}$

(分散·共分散行列)

$\left(\begin{array}{cccccccccc}107.94 & 64.53 & 27.29 & 64.02 & 43.11 & 72.25 & 33.90 & 16.16 & 30.28 & 24.73 \\ 64.53 & 155.91 & 64.03 & 66.81 & 66.77 & 47.55 & 106.20 & 41.40 & 38.41 & 43.23 \\ 27.29 & 64.03 & 103.74 & 67.27 & 63.41 & 29.85 & 57.75 & 57.61 & 34.63 & 48.13 \\ 64.02 & 66.81 & 67.27 & 109.25 & 77.35 & 56.35 & 38.15 & 43.74 & 49.49 & 38.68 \\ 43.11 & 66.77 & 63.41 & 77.35 & 160.09 & 38.35 & 61.20 & 44.07 & 35.92 & 82.84 \\ 72.25 & 47.55 & 29.85 & 56.35 & 38.35 & 60.30 & 26.40 & 24.10 & 29.45 & 26.00 \\ 33.90 & 106.20 & 57.75 & 38.15 & 61.20 & 26.40 & 98.00 & 35.40 & 21.70 & 46.75 \\ 16.16 & 41.40 & 57.61 & 43.74 & 44.07 & 24.10 & 35.40 & 41.53 & 24.17 & 33.23 \\ 30.28 & 38.41 & 34.63 & 49.49 & 35.92 & 29.45 & 21.70 & 24.17 & 33.56 & 19.51 \\ 24.73 & 43.23 & 48.13 & 38.68 & 82.84 & 26.00 & 46.75 & 33.23 & 19.51 & 56.55\end{array}\right)$

(相网行列)

$\left(\begin{array}{llllllllll}1.00 & 0.50 & 0.26 & 0.59 & 0.33 & 0.90 & 0.33 & 0.24 & 0.50 & 0.32 \\ 0.50 & 1.00 & 0.50 & 0.51 & 0.42 & 0.49 & 0.86 & 0.51 & 0.53 & 0.46 \\ 0.26 & 0.50 & 1.00 & 0.63 & 0.49 & 0.38 & 0.57 & 0.88 & 0.59 & 0.63 \\ 0.59 & 0.51 & 0.63 & 1.00 & 0.58 & 0.69 & 0.37 & 0.65 & 0.82 & 0.49 \\ 0.33 & 0.42 & 0.49 & 0.58 & 1.00 & 0.39 & 0.49 & 0.54 & 0.49 & 0.87 \\ 0.90 & 0.49 & 0.38 & 0.69 & 0.39 & 1.00 & 0.34 & 0.48 & 0.65 & 0.45 \\ 0.33 & 0.86 & 0.57 & 0.37 & 0.49 & 0.34 & 1.00 & 0.55 & 0.38 & 0.63 \\ 0.24 & 0.51 & 0.88 & 0.65 & 0.54 & 0.48 & 0.55 & 1.00 & 0.65 & 0.69 \\ 0.50 & 0.53 & 0.59 & 0.82 & 0.49 & 0.65 & 0.38 & 0.65 & 1.00 & 0.45 \\ 0.32 & 0.46 & 0.63 & 0.49 & 0.87 & 0.45 & 0.63 & 0.69 & 0.45 & 1.00\end{array}\right)$

両時期の平均值に認められる差は、ボランティアの精神的緊張による可能性が強い。第 1 期にお いては、いずれのボランティアす臨床第 1 相試験をはじめて体験するため、かなり緊張すること が予想される。特に最初の測定時刻、すなわち $8: 30$ (0hr.) において、贀張の度合が最も強いと考 えられる。しかし第 2 期においては、既に 1 回試験を経験しているため、第 1 期に比べると精神 的に落ち着いた状態で武験に臨むことが出来る。血圧、脈拍数などのいくつかの臨床検查は、精

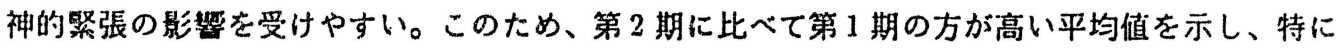
最初の測定時刻 8:30 (0hr.)において、その傾向が顕著に現わ扎たと考えられる。上述したこれ以 外の点についてむ、臨床的立場から、すべて妥当なすのである。

次節では、AIC を基隼としたモデル選択の立場から、多次元正規分布モデルをあてはめること により、対象となるデータの動き方に関する解析を試みる。

\section{2 モデル設定}

今回設定するモデルは、各データが

$$
\begin{aligned}
\left(テ^{\prime}-タ\right) & =\text { (全体の平均值) } \\
& + \text { (全体の平均值と各ボランティアの平均值との差) } \\
& + \text { (各測定点における变動) }
\end{aligned}
$$


の 3 成分に分解できるという仮定に基づいている。

この仮定に基づき、データ $x_{i}$ の成分 $x(i, p, h, b)$ を

$$
x(i, p, h, b)=\mu(\cdot, p, h, b,)+z(i, p, \cdot, b)+\varepsilon(i, p, h, b)
$$

と表わし、さらに $z(i, p, \cdot, b)$ を

$$
z(i, p, \cdot, b)=z_{0}(i, \cdot, \cdot, b)+\theta(i, p, \cdot, b)
$$

と分解する。ここで、 $z(i, p, \cdot, b)$ は各ボランティアの平均值と全体の平均值との差を表わし、この 成分は上式に示すように 2 成分 $z_{0}(i, \cdot, \cdot, b)$ と $\theta(i, p, \cdot, b)$ に分解できると仮定する。 $z_{0}(i, \cdot, \cdot, b)$ は時 期に無関係な各ボランティア固有の差を表わし、 $\theta(i, p, \cdot, b)$ は各時期における変動を表わす。

全体の平均に比べて、本来血圧が高めのボランティアは高めの值を、低めのボランティアは低 めの値をとりやすいことが予想できる。すなわち、各ボランティアはそれぞれ固有の、全体の平 均值との差を有すると考え、これを $z_{0}(i, \cdot, \cdot, b)$ で表わす。また、各ボランティアの平均值は時期 によって変動することが予想されることから、この各時期における変動 $\theta(i, p, \cdot, b)$ で表わす。

$z_{0}(i, \cdot, \cdot, b)$ と $\theta(i, p, \cdot, b)$ については、正規分布

$$
\left\{\begin{array} { l } 
{ E [ z _ { 0 } ( i , \cdot , \cdot , b ) ] = 0 } \\
{ E [ z _ { 0 } ( i , \cdot , \cdot , s ) ^ { 2 } ] = \sigma _ { s } ^ { 2 } } \\
{ E [ z _ { 0 } ( i , \cdot , \cdot , d ) ^ { 2 } ] = \sigma _ { d } ^ { 2 } } \\
{ E [ z _ { 0 } ( i , \cdot , \cdot , s ) z _ { 0 } ( i , \cdot , \cdot , d ) ] = C _ { m } }
\end{array} \quad \left\{\begin{array}{l}
E[\theta(i, p, ., b)]=0 \\
E\left[\theta(i, p, ., s)^{2}\right]=\sigma_{\theta s(p)}^{2} \\
E\left[\theta(i, p, ., d)^{2}\right]=\sigma_{\theta d(p)}^{2} \\
E[\theta(i, p, ., s) \theta(i, p, ., d)]=C_{\theta(p)}
\end{array}\right.\right.
$$

を仮定する。 $C_{m}$ と $C_{\theta(p)}$ は、各ボランティアの平均値の変動における収縮期血圧と拡張期血圧の 相関を表わす。

$\varepsilon(i, p, h, b)$ は各测定点における変動を表わし、正規分布

$$
\left\{\begin{array}{l}
E[\varepsilon(i, p, h, b)]=0 \\
E\left[\varepsilon(i, p, h, s)^{2}\right]=\sigma_{t s}^{2} \\
E\left[\varepsilon(i, p, h, d)^{2}\right]=\sigma_{t d}^{2} \\
E[\varepsilon(i, p, h, s) \varepsilon(i, p, h, d)]=C_{t} \\
\text { otherwise, covariance }=0
\end{array}\right.
$$

を仮定する。 $C_{t}$ は、各測定点の変動における収縮期血圧と拡張期血圧の相関を表わす。

すでに述べたように、データ間の相関は両時期でほぼ同一と考えられるので、

$$
\left\{\begin{array}{l}
\sigma_{\theta s(1)}=\sigma_{\theta s(2)}=\sigma_{\theta s} \\
\sigma_{\theta d(1)}=\sigma_{\theta d(2)}=\sigma_{\theta d} \\
C_{\theta(1)}=C_{\theta(2)}=C_{\theta}
\end{array}\right.
$$

と仮定する。

式（2）により表わされるモデルについて、平均値ベクトル 示す。Table 3 においては、

$$
\left\{\begin{array}{l}
\sigma_{1}^{2}=\sigma_{s}^{2}+\sigma_{t s}^{2}+\sigma_{\theta_{s}}^{2} \\
\sigma_{2}^{2}=\sigma_{d}^{2}+\sigma_{t d}^{2}+\sigma_{\theta d}^{2} \\
\rho_{1} \sigma_{1}^{2}=\sigma_{s}^{2}+\sigma_{\theta s}^{2} \\
\rho_{2} \sigma_{2}^{2}=\sigma_{d}^{2}+\sigma_{\theta d}^{2} \\
C_{m t \theta}=C_{m}+C_{t}+C_{\theta} \\
C_{m \theta}=C_{m}+C_{\theta}
\end{array}\right.
$$


とする。

このモデルを $M O D E L(\boldsymbol{\mu}, \boldsymbol{\Sigma})$ と表わす。このモデルと比較するために、次の 3 個のモデルを設 定する。

$\operatorname{MODEL}\left(\mu_{0}+\delta_{(8: 30)}, \Sigma\right):$ これは、ボランティアの精神的緊張による影響が 8:30 (0hr.) のみに

認められると仮定するそデルである。 $\mu(\cdot, p, h, b$,$) を \mu_{0}(\cdot, \cdot, h, b)+\delta(\cdot, p, h, b)$ と分解する。 $\delta(\cdot, p, h, b)$ は、ボランティアの精神的緊張により生じた両時期の平均值の差を表わす。ここ では、 $\delta(\cdot, 1,0, s)=\delta_{s}, \delta(\cdot, 1,0, d)=\delta_{d}, \delta(\cdot, p, h, b)=0$ (otherwise) とおく。

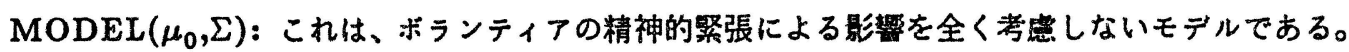
上述のモデルで、 $\delta(\cdot, p, h, b)$ を 0 に固定したものに等しい。

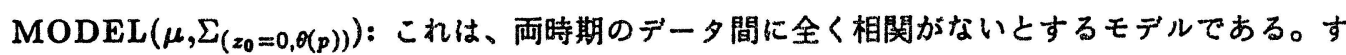
なわち、同一の 20 人のボランティアから得られたデータを、20人ずつの相異なる 2 つのク ループから得られたデータとして扱うモデルである。

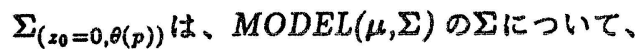

$$
\left\{\begin{array}{l}
\sigma_{s}=\sigma_{d}=0 \\
C_{m}=0 \\
\sigma_{\theta s(1)} \neq \sigma_{\theta s(2)} \\
\sigma_{\theta d(1)} \neq \sigma_{\theta d(2)} \\
C_{\theta(1)} \neq C_{\theta(2)}
\end{array}\right.
$$

とおくことを意味する。

以上の 4 個のモデルをあてはめ、AIC を基準とした此較を行なう。MODEL( $\mu, \Sigma)$ の自由バラ メータは

$$
\begin{gathered}
\mu=(\mu(\cdot, 1,0, s), \cdots, \mu(\cdot, 1,4, d), \mu(\cdot, 2,0, s), \cdots, \mu(\cdot, 2,4, d))^{T}, \\
\sigma_{1}, \sigma_{2}, \sigma_{s}, \sigma_{d}, \rho_{1}, \rho_{2}, C_{m}, C_{m \theta}, C_{m t \theta}
\end{gathered}
$$

である。式(3)により、上哭のパラメータの值から、その他のバラメータの值は全て計算できる。

\section{4 結果}

Davidon 法 (Davidon[2], Ishiguro and Akaike[3]) を用いた数值的最適化により計算した AIC の值を Table 4 に示す。AIC の值から、以下の点が示唆される。

1. $\operatorname{MODEL}\left(\mu_{0}, \Sigma\right)$ に比べて $M O D E L(\mu, \Sigma)$ AIC の値が小さいことから、雨時期の平均值に は有意な差がある。

2. $\operatorname{MODEL}\left(\boldsymbol{\mu}, \Sigma_{\left(x_{0}=0, \theta(p)\right)}\right)$ に比べて $\operatorname{MODEL}(\mu, \Sigma)$ のIC の值が小さいことから、両時期の データ間には有意な相関がある。

3. $\operatorname{MODEL}(\boldsymbol{\mu}, \boldsymbol{\Sigma})$ に比べて $\operatorname{MODEL}\left(\mu_{0}+\delta_{(8: 30)}, \boldsymbol{\Sigma}\right)$ の AIC の值が小さいことから、両時期の 平均值の差は 8:30 (0hr.) のみに認められる。 


$$
\begin{aligned}
& \text { Table 3. } \mu \text { and } \Sigma \\
& \mu=\left(\begin{array}{c}
\mu_{(1)} \\
\mu_{(2)}
\end{array}\right) \mu_{(p)}=\left(\begin{array}{c}
\mu(\cdot, p, 0, s) \\
\mu(\cdot, p, 1, s) \\
\vdots \\
\mu(\cdot, p, 4, s) \\
\mu(\cdot, p, 0, d) \\
\mu(\cdot, p, 1, d) \\
\vdots \\
\mu(\cdot, p, 4, d)
\end{array}\right) \Sigma=\left(\begin{array}{cc}
\Sigma_{1} & \Sigma_{2} \\
\Sigma_{2} & \Sigma_{1}
\end{array}\right)
\end{aligned}
$$

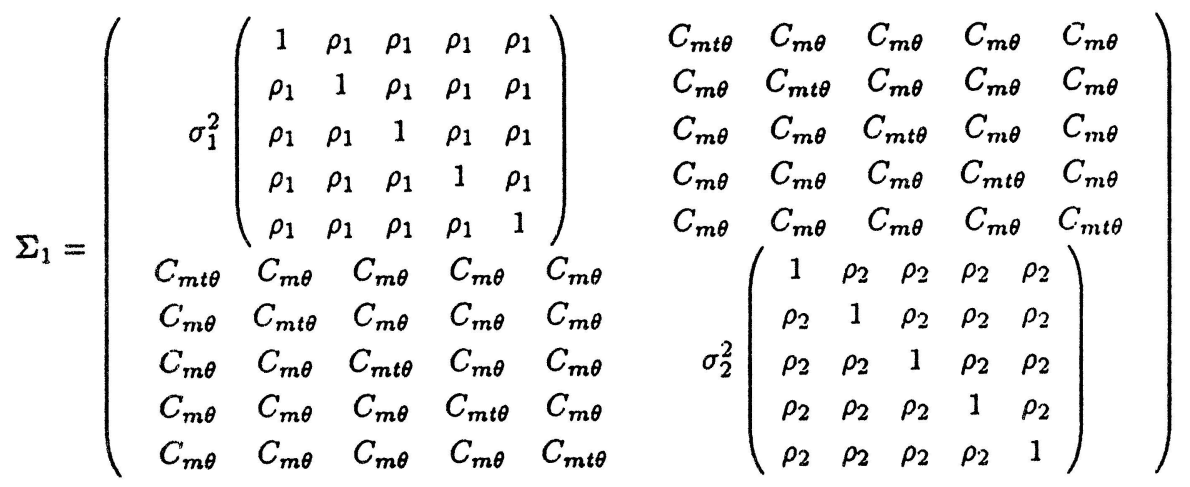

$$
\begin{aligned}
& \boldsymbol{\Sigma}_{2}=\left(\begin{array}{cccccccccc}
\sigma_{s}^{2} & \sigma_{s}^{2} & \sigma_{s}^{2} & \sigma_{s}^{2} & \sigma_{s}^{2} & C_{m} & C_{m} & C_{m} & C_{m} & C_{m} \\
\sigma_{s}^{2} & \sigma_{s}^{2} & \sigma_{s}^{2} & \sigma_{s}^{2} & \sigma_{s}^{2} & C_{m} & C_{m} & C_{m} & C_{m} & C_{m} \\
\sigma_{s}^{2} & \sigma_{s}^{2} & \sigma_{s}^{2} & \sigma_{s}^{2} & \sigma_{s}^{2} & C_{m} & C_{m} & C_{m} & C_{m} & C_{m} \\
\sigma_{s}^{2} & \sigma_{s}^{2} & \sigma_{s}^{2} & \sigma_{s}^{2} & \sigma_{s}^{2} & C_{m} & C_{m} & C_{m} & C_{m} & C_{m} \\
\sigma_{s}^{2} & \sigma_{s}^{2} & \sigma_{s}^{2} & \sigma_{s}^{2} & \sigma_{s}^{2} & C_{m} & C_{m} & C_{m} & C_{m} & C_{m} \\
C_{m} & C_{m} & C_{m} & C_{m} & C_{m} & \sigma_{d}^{2} & \sigma_{d}^{2} & \sigma_{d}^{2} & \sigma_{d}^{2} & \sigma_{d}^{2} \\
C_{m} & C_{m} & C_{m} & C_{m} & C_{m} & \sigma_{d}^{2} & \sigma_{d}^{2} & \sigma_{d}^{2} & \sigma_{d}^{2} & \sigma_{d}^{2} \\
C_{m} & C_{m} & C_{m} & C_{m} & C_{m} & \sigma_{d}^{2} & \sigma_{d}^{2} & \sigma_{d}^{2} & \sigma_{d}^{2} & \sigma_{d}^{2} \\
C_{m} & C_{m} & C_{m} & C_{m} & C_{m} & \sigma_{d}^{2} & \sigma_{d}^{2} & \sigma_{d}^{2} & \sigma_{d}^{2} & \sigma_{d}^{2} \\
C_{m} & C_{m} & C_{m} & C_{m} & C_{m} & \sigma_{d}^{2} & \sigma_{d}^{2} & \sigma_{d}^{2} & \sigma_{d}^{2} & \sigma_{d}^{2}
\end{array}\right)
\end{aligned}
$$

Table 4. AIC

\begin{tabular}{|c|c|c|}
\hline モデル & 自由パラメータ数 & AIC \\
\hline $\operatorname{MODEL}\left(\mu_{0}+\delta_{(8: 30)}, \Sigma\right)$ & 21 & 2653.05 \\
\hline $\operatorname{MODEL}(\mu, \Sigma)$ & 29 & 2662.15 \\
\hline $\operatorname{MODEL}\left(\mu, \Sigma_{\left(z_{0}=0, \theta(p)\right)}\right.$ & 32 & 2669.64 \\
\hline $\operatorname{MODEL}\left(\mu_{0}, \Sigma\right)$ & 19 & 2674.72 \\
\hline
\end{tabular}


すべてのモデルの中で、MODEL $\left(\mu_{0}+\delta_{(8: 30)}, \Sigma\right)$ のIC の值が最す小さいことから、これを 最通なモデルとして選択する。同一のボランティアから 2 日の間隔しか置かずに測定したデータ であろことから、この結果は臨床的に妥当なるのである。

$M O D E L\left(\mu_{0}+\delta_{(8: 30)}, \Sigma\right)$ のパラメータの值をTable 5 に、また、データ間の相関係数を Table 6 に示す。

パラメータおよび相関係数の值から、以下の点が示唆される。

1. 各測定点における収縮期血圧と抎張期血圧のデータ間には、高い正の相関がある。

2. 各時期において、収縮期血圧のデータ間および拡張期血圧のデータ間には、それぞれ正の相 関がある。

3. 両時期の収縮期血圧のデー夕間および拓張期のデー夕間には、それぞれ正の相関がある。こ の相関は、上述した各時期における相関に比べると、収縮期血厌、搪張期血圧のいずれにお いてもやや低い。

4. $\delta_{s}$ と $\delta_{d}$ の值から、第 1 期の 8:30 (0hr.) の平均值は第 2 期の平均值に比へ、収縮期血圧、拡張 期血圧のいずれにおいても約 $10 \mathrm{mmHg}$ 高い。

5. $\sigma_{s} 、 \sigma_{d 、} \sigma_{\theta s} 、 \sigma_{\theta d}$ の值から、各ボランティアのデータは時期により变動するが、ボランティ フ間の変動に比べると時期による変動は小さい。

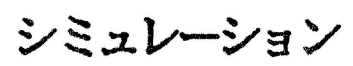

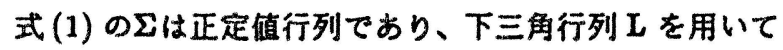

$$
\mathbf{\Sigma}=\mathbf{L} \mathbf{L}^{T}
$$

と分解できる。

$k$-次元ベクトル $X=\left(X_{1}, X_{2}, \cdots, X_{k}\right)^{T}$ が $k$-次元正規分布に従うとき、

$$
Y=\mathrm{L}^{-1}(X-\mu)
$$

によって定義される $Y=\left(Y_{1}, Y_{2}, \cdots, Y_{k}\right)^{T}$ の各成分 $Y_{1}, Y_{2}, \cdots, Y_{k}$ は、互いに独立に正規分布 $N(0,1)$ に従う。式(4)より

$$
X=L Y+\mu
$$

が得られる。

式(5)により、各成分が互いに独立に正規分布 $N(0,1)$ に従う20-次元へクトルyを用いて、20次元ベクトルのデータxを

$$
x=\mathrm{L} y+\mu
$$

によってシミュレーション出来る。

$\operatorname{MODEL}\left(\mu_{0}+\delta_{(8: 30)}, \boldsymbol{\Sigma}\right)$ を用いたシミュイレーションの結果について、その数值を Appendix に、グラフを Figure 3-1 Figure 4-2 に示す。

シミュレーションの結果得られた血圧の值は、脈圧差（収縮期血圧と拡張期血圧の差）引含 めて、健康成人男子から得られた值として、臨床的に妥当なるのである。また、グラフには 8:30 (Ohr.) における両時期間の平均值の差が明確に表われている。 
Table 5. パラメータ

\begin{tabular}{|c|c|}
\hline 平均値 (Systole) & $103.89,113.09,110.24,109.14,109.24$ \\
\hline 平均値 (Diastole) & $63.28,68.73,66.98,65.78,67.10$ \\
\hline$\delta_{s}$ & 10.46 \\
\hline$\delta_{d}$ & 9.79 \\
\hline$\sigma_{1}$ & 11.29 \\
\hline$\sigma_{2}$ & 8.25 \\
\hline$\sigma_{s}$ & 6.78 \\
\hline$\sigma_{d}$ & 5.38 \\
\hline$\sigma_{\theta s}$ & 4.91 \\
\hline$\sigma_{\theta d}$ & 2.66 \\
\hline$\sigma_{t s}$ & 7.58 \\
\hline$\sigma_{t d}$ & 5.66 \\
\hline$\rho_{1}$ & 0.55 \\
\hline$\rho_{2}$ & 0.53 \\
\hline$C_{m t \theta}$ & 76.96 \\
\hline$C_{m \theta}$ & 49.66 \\
\hline$C_{m}$ & 36.76 \\
\hline$C_{\theta}$ & 12.90 \\
\hline$C_{t}$ & 27.30 \\
\hline
\end{tabular}

Table 6. 相関係数

\begin{tabular}{|c|c|}
\hline 各時期の収縮期間 $\left(\rho_{1}\right)$ & 0.55 \\
\hline 各時期の拡張期間 $\left(\rho_{2}\right)$ & 0.53 \\
\hline 各測定点における収縮期と拡張期間 & 0.83 \\
\hline 両時期の収縮期間 & 0.36 \\
\hline 両時期の拡張期間 & 0.43 \\
\hline
\end{tabular}

\section{6 結論}

本論文では、臨床第 1 相試験において健康成人男子ボランティア 20 人から、投薬のない状 態で測定されたデータに対して多次元正規分布モデルをあてはめ、AIC を基準として、データの 動き方に関する最適なモデルの選択を試みた。

その結果、MODEL $\left(\mu_{0}+\delta_{(8: 30)}, \boldsymbol{\Sigma}\right)$ が選択さ机、このモデルに関するパラメータの計算上こ のモデルによるシミュレーションを行なった。シミュレーションの結果は、臨床的に妥当なすの であった。

$M O D E L\left(\mu_{0}+\delta_{(8: 30)}, \Sigma\right)$ には、次のような特徴がある。

1. 各測定点における収縮期血圧と拡張期血圧のデータ間には、高い正の相関がある。

2. 各時期において、収縮期血圧のデータ間および拡張期血圧のデータ間には、それぞれ正の相 関がある。

3. 両時期の収縮期血圧のデー夕間および拡張期のデータ間には、それぞれ正の相関がある。こ の相関は、上述した各時期における相関に比べると、収宿期血圧、拡張期血圧のいず扎におう いてあやや低い。 
4. $8: 30$ (0hr.) の平均值は第 2 期の平均値に比べて、収縮期血圧、拡張期血圧のいずれにおいて す第 1 期の方がやや高い。これは、ボランティアの精神的㗨張による影掣と考えられる。

これらの特徽は、臨床的にす極めて妿当なるのである。

このモデルを用いて、最初の数個のデータからそれ以降のデータの動きを予测することが可能 である。この予测された野きと、投薬時のデー夕の動きとを比較することによって、薬凨による

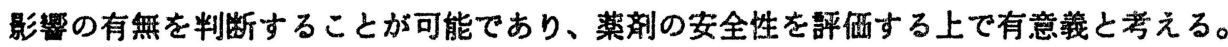

今回解析対缶となったデータでは、1 回の测定で収縮期血圧と拡張期血圧の 2 個のデータが得 られ、同一のボランティアについて、時期を变えて 2 回测定を行なっている。臨床第 1 相試験で は、これ以外にも様々なタイプのデータが得られる。例えば

- 1 回の測定で 2 個以上のデータが測定されるすの

- 同一のボランティアについて、2 期以上にわたって測定が行なわれるすの

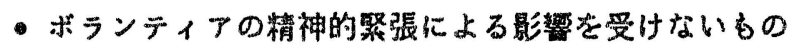

などである。このようなデータは、臨床第 1 相試験のみならず、それ以外の様々な臨床分野にお いても数多く得られる。

これらのデータに対しても、本論文で提示したそデルが適用可能である。すなわち、

1. 血圧と同様に精神的緊張の影珤を受ける可能性があるデータが、1 回の測定で 2 個以上得ら れる場合には、MODEL $\left(\mu_{0}+\delta_{(8: 30)}, \Sigma\right)$ を拡張できる。

2. 同一ボランティアにつき、2 時期以上にわたり测定が行なわれる場合には、MODEL $\left(\mu_{0}+\right.$ $\left.\delta_{(8: 30)}, \Sigma\right)$ を搪張できる。

3. データがボランティアの精神的緊張による影留を受けない場合には、MODEL $\left(\mu_{0}, \Sigma\right)$ が適 用できる。

以上の点から、本論文で提示したモデルは、臨床第1相試験のみならず、それ以外の臨床分野に おいてす道用可能と考える。

\section{约辞}

本䅻の執筆に際し御協力を頂いた、北里研究所パイオイフトリックセンター臨床薬理部門占田 久子さんに感搠致します。

本研究は、統計数理研究所栶別共同研究（1－共研－24）により、行なわれたすのである。 


\section{参考文献}

[1] Akaike, H. (1973). Information theory and an extension of the maximum likelihood principle, 2nd Inter. Symp. on Information Theory (Petrov, B. N. and Csaki, F. eds.), Akademiai Kiado, Budapest, 267-281.

[2] Davidon, W.C. (1968). Variance Algorithm for Minimization. Computer Journal, 10, 406410.

[3] Ishiguro, M. and Akaike, H. (1989). DALL: Davidon's Algorithm for Log Likelihood Maximization - A FORTRAN subroutine for statistical model builders -. Computer Science Monographs, No.25, The Institute of Statistical Mathematics, Tokyo.

[4] Sakamoto, Y., Ishiguro, M. and Kitagawa, G. (1986). Akaike Information Criterion Statistics. Reidel, Dordrecht, Holland.

[5] Yafune, A. and Ishiguro, M. (1990). A MODEL FOR TIME SERIES DATA OF HUMAN BLOOD PRESSURE IN CLINICAL PHASE-ONE STUDY. Bulletin of the Biometric Society of Japan, Vol.11, No.1 \& No.2, 9-27 
Appendix

1. Original Data (First Period)

Systolic Blood Pressure ( $\mathrm{mmHg}$ )

$\begin{array}{rrrrrr}\text { (No.) } & (8: 30) & (10: 00) & (11: 00) & (12: 00) & (13: 00) \\ 1 & 112 & 126 & 113 & 119 & 111 \\ 2 & 113 & 114 & 110 & 114 & 116 \\ 3 & 137 & 135 & 145 & 137 & 142 \\ 4 & 117 & 104 & 103 & 118 & 114 \\ 5 & 124 & 112 & 119 & 106 & 116 \\ 6 & 117 & 121 & 111 & 99 & 138 \\ 7 & 141 & 126 & 111 & 124 & 110 \\ 8 & 126 & 124 & 119 & 115 & 118 \\ 9 & 107 & 114 & 99 & 99 & 99 \\ 10 & 105 & 126 & 107 & 116 & 105 \\ 11 & 113 & 114 & 113 & 110 & 111 \\ 12 & 114 & 111 & 120 & 105 & 99 \\ 13 & 106 & 119 & 106 & 112 & 96 \\ 14 & 101 & 94 & 95 & 106 & 94 \\ 15 & 109 & 111 & 98 & 97 & 100 \\ 16 & 105 & 92 & 105 & 104 & 100 \\ 17 & 113 & 119 & 113 & 106 & 103 \\ 18 & 105 & 97 & 102 & 105 & 100 \\ 19 & 107 & 96 & 108 & 103 & 94 \\ 20 & 126 & 124 & 126 & 113 & 123\end{array}$

Diastolic Blood Pressure ( $\mathrm{mmHg}$ )

$\begin{array}{rrrrrr}\text { (No.) } & (8: 30) & (10: 00) & (11: 00) & (12: 00) & (13: 00) \\ 1 & 67 & 72 & 62 & 75 & 61 \\ 2 & 78 & 66 & 73 & 70 & 68 \\ 3 & 91 & 95 & 90 & 87 & 92 \\ 4 & 78 & 67 & 65 & 65 & 63 \\ 5 & 83 & 76 & 66 & 69 & 67 \\ 6 & 74 & 85 & 63 & 61 & 79 \\ 7 & 98 & 81 & 69 & 68 & 75 \\ 8 & 80 & 87 & 82 & 67 & 67 \\ 9 & 70 & 66 & 74 & 62 & 63 \\ 10 & 69 & 75 & 65 & 66 & 70 \\ 11 & 74 & 67 & 70 & 66 & 81 \\ 12 & 66 & 66 & 73 & 62 & 55 \\ 13 & 64 & 65 & 63 & 60 & 64 \\ 14 & 67 & 52 & 60 & 68 & 63 \\ 15 & 65 & 72 & 55 & 51 & 60 \\ 16 & 67 & 58 & 66 & 65 & 63 \\ 17 & 66 & 73 & 62 & 68 & 75 \\ 18 & 71 & 56 & 62 & 61 & 59 \\ 19 & 68 & 61 & 65 & 58 & 55 \\ 20 & 72 & 70 & 78 & 67 & 74\end{array}$




\begin{tabular}{|c|c|c|c|c|c|}
\hline \multicolumn{6}{|c|}{ 1. Original Data (Second Period) } \\
\hline \multicolumn{6}{|c|}{ Systolic Blood Pressure $(\mathrm{mmHg})$} \\
\hline (No.) & $(8: 30)$ & $(10: 00)$ & $(11: 00)$ & $(12: 00)$ & $(13: 00)$ \\
\hline 1 & 90 & 131 & 126 & 105 & 110 \\
\hline 2 & 102 & 98 & 108 & 114 & 113 \\
\hline 3 & 117 & 130 & 126 & 120 & 132 \\
\hline 4 & 92 & 106 & 106 & 101 & 91 \\
\hline 5 & 116 & 116 & 120 & 126 & 111 \\
\hline 6 & 104 & $10 \pi$ & 84 & 90 & 91 \\
\hline 7 & 121 & 119 & 120 & 113 & 110 \\
\hline 8 & 105 & $12 \pi$ & 118 & 121 & 109 \\
\hline 9 & 119 & $12 T$ & 113 & 106 & 112 \\
\hline 10 & 118 & 124 & 115 & 132 & 127 \\
\hline 11 & 106 & 115 & 105 & 110 & 129 \\
\hline 12 & 94 & 104 & 109 & 107 & 85 \\
\hline 13 & 105 & 110 & 98 & 104 & 105 \\
\hline 14 & 104 & 104 & 115 & 103 & 104 \\
\hline 15 & 99 & 102 & 99 & 109 & 110 \\
\hline 16 & 99 & 90 & 101 & 94 & 96 \\
\hline 17 & 81 & 94 & 115 & 101 & 126 \\
\hline 18 & 97 & 97 & 102 & 95 & 97 \\
\hline 19 & 96 & 126 & 101 & 100 & 108 \\
\hline 20 & 103 & 119 & 107 & 108 & 116 \\
\hline \multicolumn{6}{|c|}{ Diastolic Blood Pressure $(\mathrm{mm} \mathrm{Hg}$ ) } \\
\hline (No.) & $(8: 30)$ & $(10: 00)$ & $(11: 00)$ & $(12: 00)$ & $(13: 00)$ \\
\hline 1 & 53 & 89 & 71 & 63 & 69 \\
\hline 2 & 66 & 57 & 66 & 70 & 69 \\
\hline 3 & 78 & 86 & 82 & 73 & 86 \\
\hline 4 & 54 & 57 & 65 & 59 & 56 \\
\hline 5 & 75 & 68 & 70 & 70 & 68 \\
\hline 6 & 62 & 61 & 54 & 60 & 50 \\
\hline 7 & 72 & 64 & 67 & 75 & 66 \\
\hline 8 & 70 & 75 & 77 & 78 & 69 \\
\hline 9 & 67 & 83 & 66 & 62 & 72 \\
\hline 10 & 72 & 66 & 71 & 72 & 67 \\
\hline 11 & 61 & 73 & 61 & 67 & 75 \\
\hline 12 & 56 & 61 & 63 & 67 & 55 \\
\hline 13 & 67 & 65 & 61 & 60 & 68 \\
\hline 14 & 64 & 66 & 67 & 65 & 66 \\
\hline 15 & 55 & 64 & 58 & 65 & 63 \\
\hline 16 & 56 & 49 & 58 & 54 & 60 \\
\hline 17 & 50 & 59 & 71 & 63 & 73 \\
\hline 18 & 60 & 59 & 64 & 61 & 64 \\
\hline 19 & 56 & 68 & 62 & 65 & 66 \\
\hline 20 & 66 & 70 & 63 & 67 & 69 \\
\hline
\end{tabular}




\begin{tabular}{|c|c|c|c|c|}
\hline \multicolumn{5}{|c|}{ 2. Simulation (First Period) } \\
\hline$(8: 30)$ & $(10: 00)$ & $(11: 00)$ & $(12: 00)$ & (13: \\
\hline 7.05 & & & & \\
\hline 7.9 & & & & \\
\hline 1. & & & & \\
\hline 0.50 & & & & .00 \\
\hline 1.5 & & & & \\
\hline 6.0 & & 11 & & \\
\hline 39 & & & & \\
\hline 1.6 & & 9 & & .90 \\
\hline 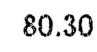 & & & & 6.62 \\
\hline 7.22 & 13 & 119.98 & & 65 \\
\hline 20 & & & & \\
\hline 80.3 & & & & 87 \\
\hline 7.0 & 12 & 11 & & .09 \\
\hline 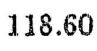 & 10 & o & & 36 \\
\hline 62 & 12 & 1 & & .18 \\
\hline 11.5 & 108.05 & & & 0.99 \\
\hline 5.5 & & & & 104.73 \\
\hline & & & & 91.10 \\
\hline & & & & 09.44 \\
\hline & 133.08 & 109.67 & 110.04 & 107.4 \\
\hline
\end{tabular}

Diastolic Blood Pressure ( $\mathrm{mmHg}$ )

$\begin{array}{rrrrr}(8: 30) & (10: 00) & (11: 00) & (12: 00) & (13: 00) \\ 75.93 & 83.07 & 66.26 & 88.36 & 71.34 \\ 70.51 & 56.60 & 58.81 & 52.27 & 59.42 \\ 63.05 & 59.13 & 55.43 & 68.28 & 75.50 \\ 48.81 & 58.76 & 55.33 & 56.51 & 48.89 \\ 66.66 & 65.32 & 55.30 & 57.77 & 61.70 \\ 64.18 & 63.98 & 68.13 & 59.97 & 66.09 \\ 60.95 & 49.27 & 55.86 & 48.76 & 55.83 \\ 67.30 & 61.56 & 50.83 & 55.63 & 58.37 \\ 47.28 & 48.20 & 68.06 & 52.16 & 51.11 \\ 88.44 & 76.05 & 76.47 & 78.37 & 77.37 \\ 66.84 & 50.80 & 57.69 & 51.10 & 61.37 \\ 50.25 & 68.20 & 56.42 & 69.00 & 53.48 \\ 77.95 & 65.52 & 62.01 & 78.86 & 74.58 \\ 73.98 & 65.27 & 84.82 & 61.49 & 70.84 \\ 81.86 & 71.66 & 74.45 & 73.11 & 72.70 \\ 57.29 & 69.90 & 57.15 & 61.88 & 46.47 \\ 62.27 & 52.06 & 48.42 & 51.21 & 71.88 \\ 63.62 & \mathbf{7 5 . 9 4} & 65.87 & 72.96 & 53.58 \\ \mathbf{7 5 . 2 5} & 62.23 & 65.21 & 65.01 & 61.02 \\ 63.98 & 81.59 & 68.81 & 66.96 & \mathbf{7 6 . 6 0}\end{array}$


2. Simulation (Second Period)

Systolic Blood Pressure ( $\mathrm{mmHg}$ )

$\begin{array}{rrrrr}(8: 30) & (10: 00) & (11: 00) & (12: 00) & (13: 00) \\ 113.82 & 123.25 & 131.25 & 115.76 & 122.21 \\ 86.72 & 86.64 & 89.96 & 83.09 & 81.86 \\ 109.06 & 103.91 & 99.92 & 109.91 & 107.86 \\ 100.35 & 108.32 & 95.05 & 86.49 & 96.52 \\ 70.53 & 86.54 & 101.12 & 94.57 & 83.35 \\ 101.95 & 117.74 & 104.21 & 105.34 & 95.93 \\ 105.67 & 107.27 & 96.55 & 99.63 & 101.40 \\ 90.38 & 92.83 & 91.34 & 92.75 & 70.99 \\ 85.91 & 87.84 & 95.26 & 85.59 & 98.45 \\ 108.94 & 126.53 & 122.04 & 120.83 & 130.65 \\ 90.72 & 94.33 & 109.58 & 99.06 & 99.34 \\ 86.87 & 106.78 & 92.48 & 83.88 & 91.85 \\ 108.30 & 129.06 & 125.06 & 109.37 & 109.62 \\ 96.43 & 116.10 & 107.14 & 101.78 & 117.28 \\ 117.69 & 113.06 & 107.71 & 113.15 & 123.26 \\ 88.33 & 99.96 & 100.28 & 114.23 & 88.00 \\ 94.46 & 100.35 & 84.63 & 115.89 & 106.98 \\ 97.96 & 108.03 & 104.18 & 99.93 & 95.83 \\ 96.96 & 106.85 & 98.20 & 89.83 & 95.96 \\ 100.62 & 137.68 & 111.03 & 113.46 & 117.15\end{array}$

Diastolic Blood Pressure ( $\mathrm{mmHg}$ )

$\begin{array}{rrrrr}(8: 30) & (10: 00) & (11: 00) & (12: 00) & (13: 00) \\ 77.71 & 79.12 & 76.19 & 78.29 & 77.33 \\ 52.76 & 49.48 & 55.89 & 53.89 & 51.87 \\ 72.29 & 64.55 & 64.97 & 61.26 & 65.50 \\ 56.46 & 63.61 & 64.01 & 51.26 & 68.01 \\ 43.77 & 51.03 & 60.69 & 51.88 & 49.83 \\ 53.01 & 70.75 & 69.44 & 65.59 & 55.40 \\ 61.94 & 61.97 & 55.28 & 59.05 & 65.15 \\ 48.10 & 60.03 & 55.39 & 48.95 & 46.04 \\ 45.50 & 47.06 & 56.87 & 47.58 & 52.73 \\ 65.88 & 77.31 & 86.97 & 70.20 & 82.74 \\ 54.11 & 63.12 & 64.23 & 53.80 & 51.94 \\ 47.60 & 68.24 & 55.67 & 37.28 & 60.39 \\ 69.95 & 78.79 & 78.58 & 63.83 & 71.79 \\ 56.24 & 66.85 & 58.87 & 58.67 & 73.50 \\ 73.27 & 65.92 & 69.61 & 67.26 & 70.82 \\ 44.44 & 57.09 & 54.39 & 67.93 & 55.33 \\ 51.64 & 56.57 & 54.58 & 69.53 & 58.73 \\ 51.66 & 61.42 & 55.95 & 54.79 & 60.75 \\ 61.15 & 67.62 & 61.75 & 51.82 & 71.24 \\ 69.24 & 88.51 & 66.80 & 70.62 & 77.33\end{array}$



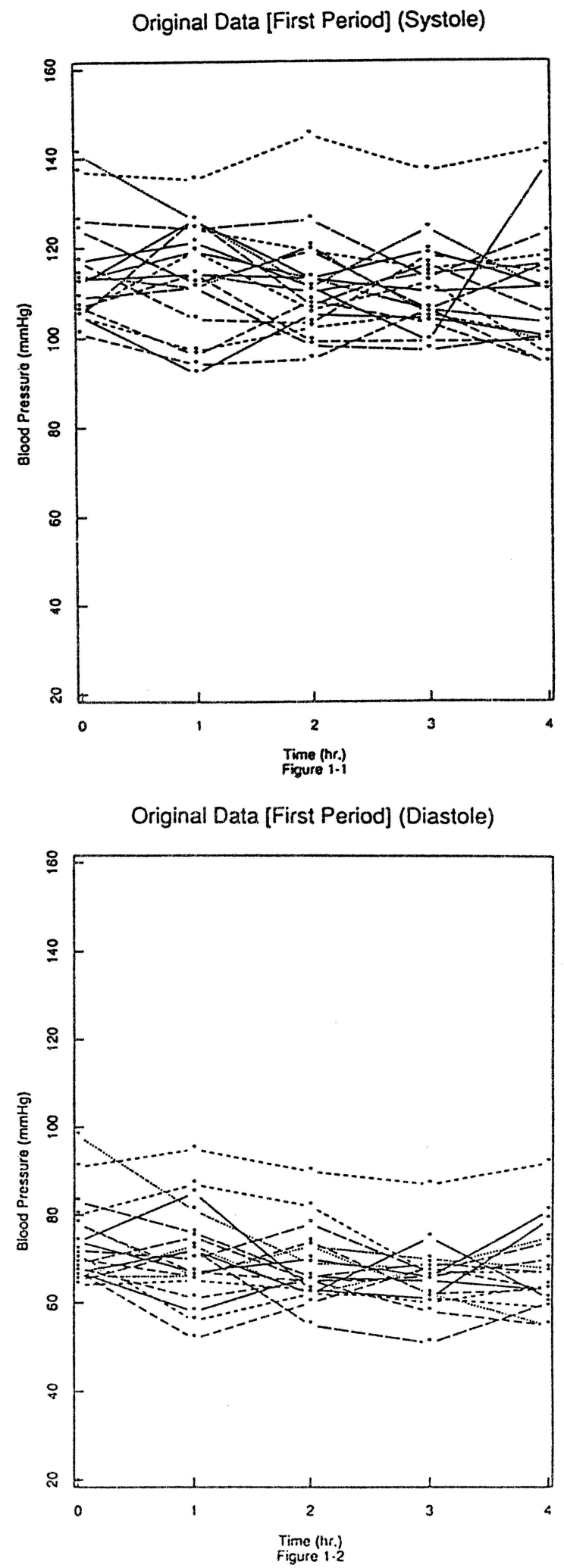

$-30-$ 
Original Data [Second Period] (Systole)

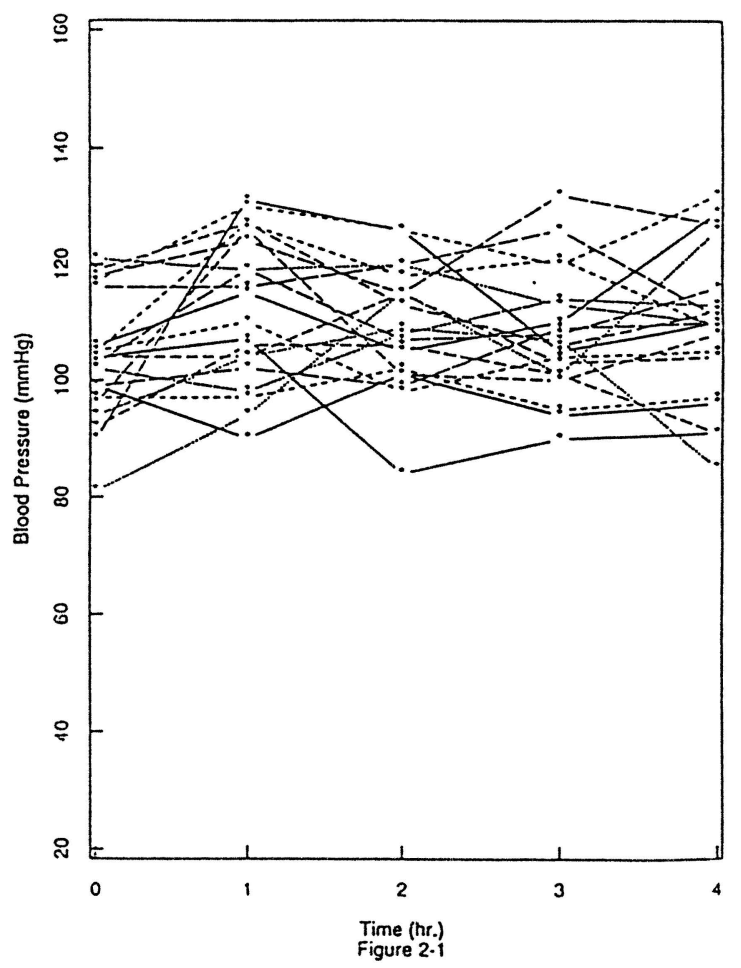

Original Data [Second Period] (Diastole)

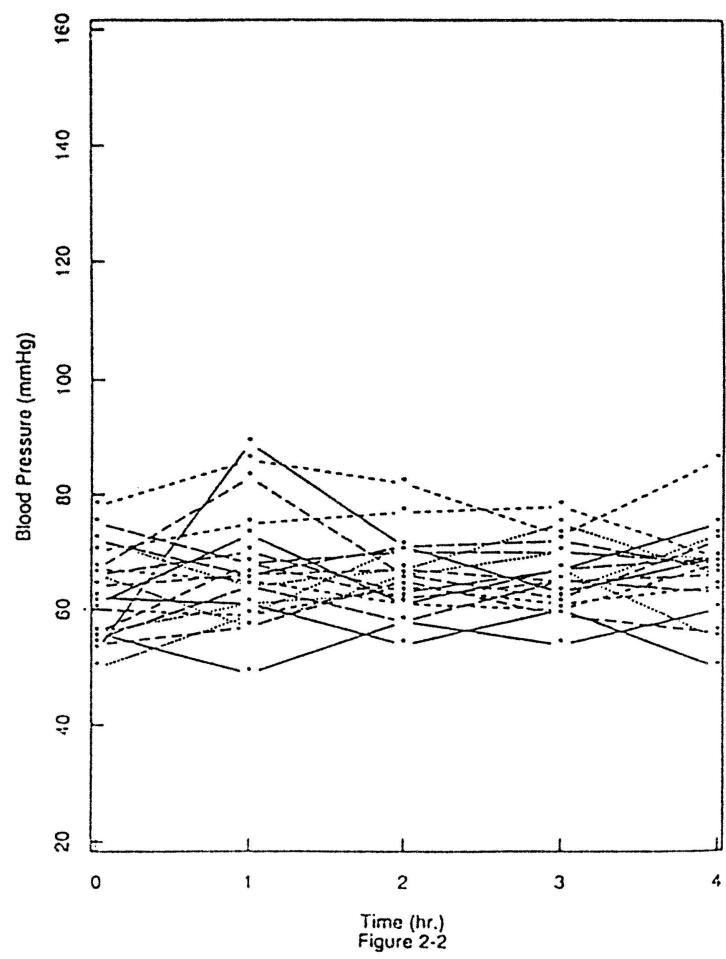


Simulation [First Period] (Systole)

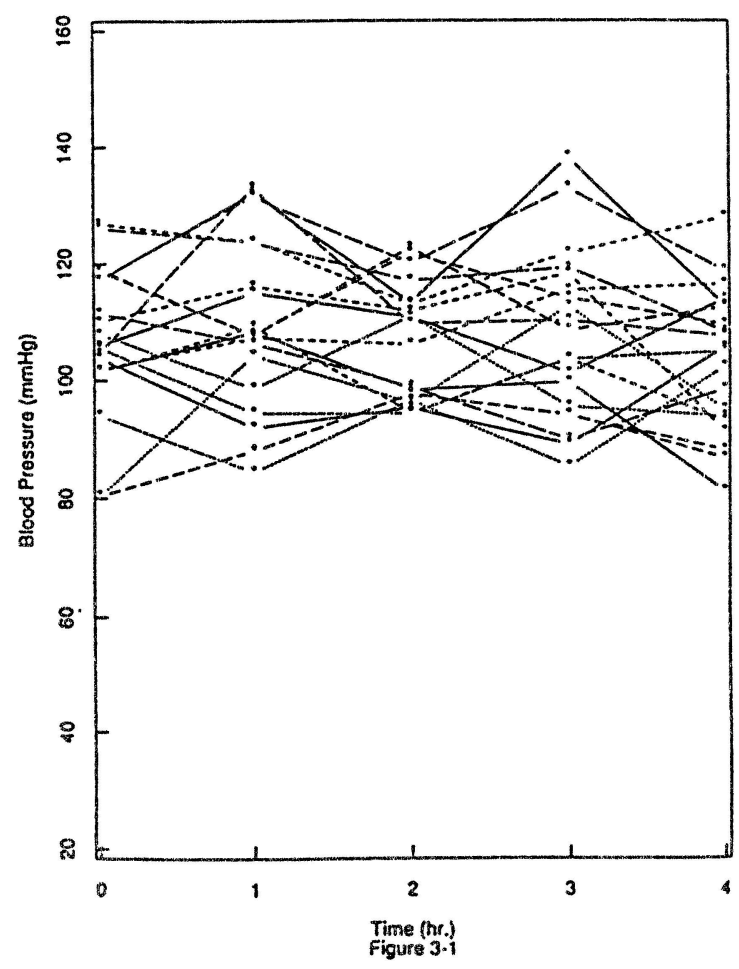

Simulation [First Period] (Diastole)

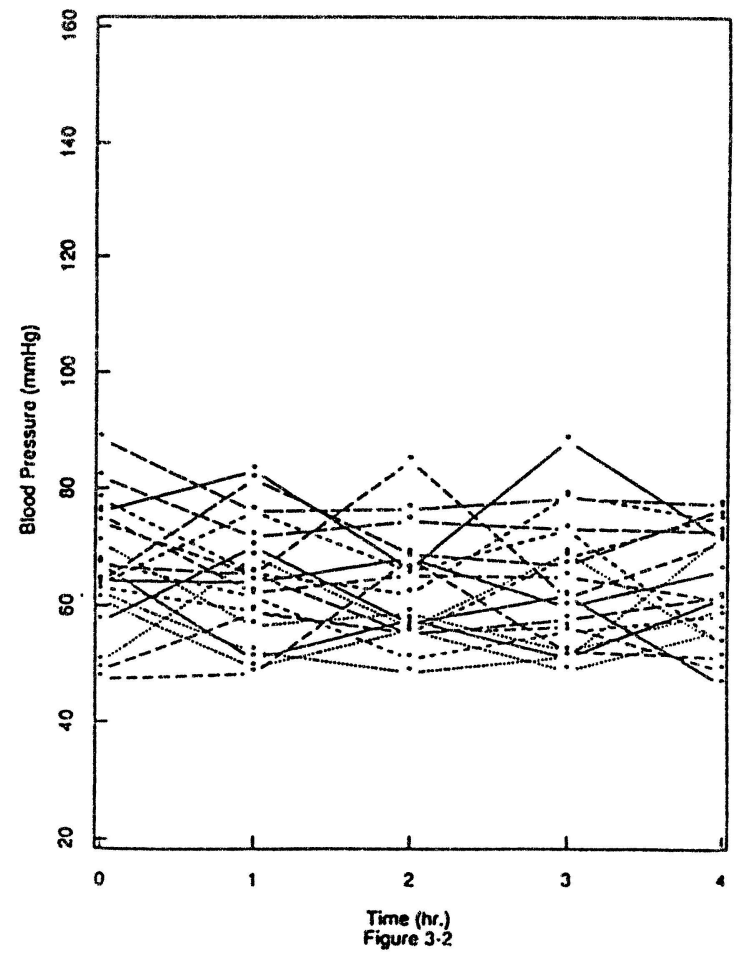


Simulation [Second Period] (Systole)

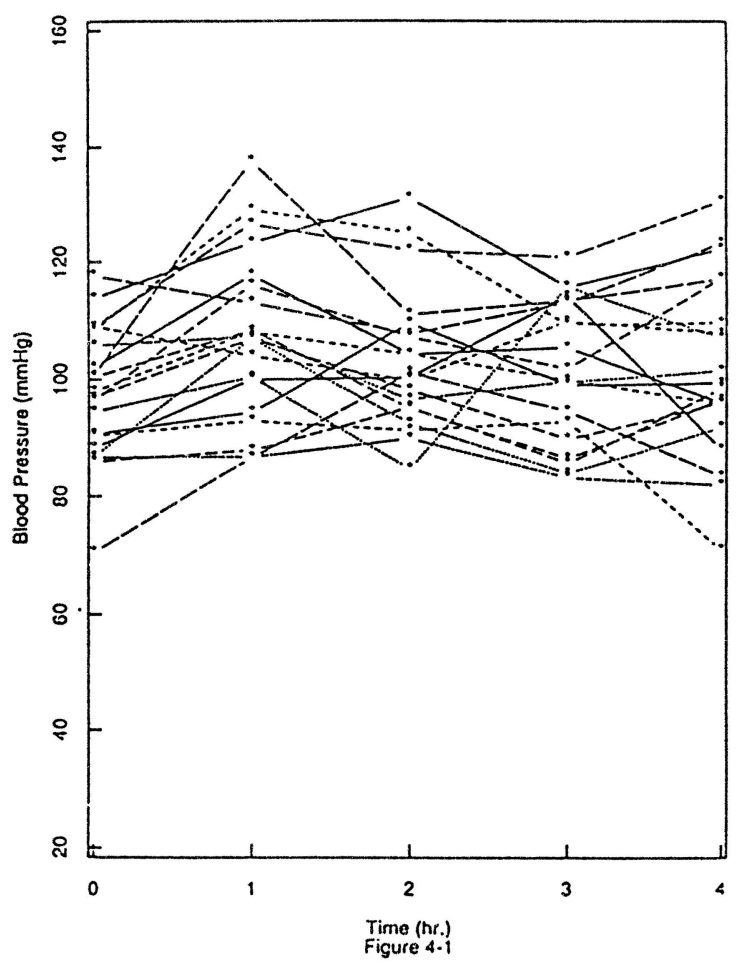

Simulation [Second Period] (Diastole)

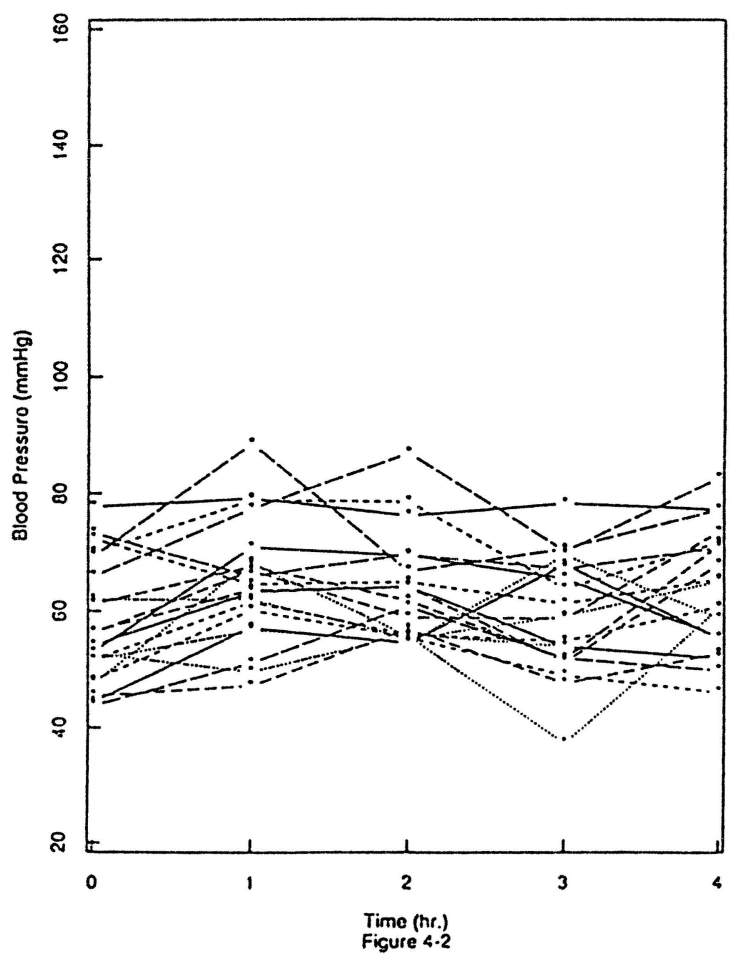

[Received May, 1991] 